\title{
PRINCIPAL COMPONENT ANALYSIS OF SOME QUANTITATIVE AND QUALITATIVE TRAITS IN IRANIAN SPINACH LANDRACES
}

\author{
Mehdi Mohebodini ${ }^{1}$, Naser Sabaghnia ${ }^{2, \#}$, Farhad Behtash ${ }^{3}$, \\ and Mohsen Janmohammadi ${ }^{2}$ \\ ${ }^{1}$ Faculty of Agriculture, University of Mohaghegh Ardabili, IRAN \\ ${ }^{2}$ Faculty of Agriculture, University of Maragheh, P.O. Box 55181-83111, Maragheh, IRAN \\ ${ }^{3}$ Faculty of Agriculture, University of Maragheh, Maragheh, IRAN \\ \# Corresponding author, \\ sabaghnia@maragheh.ac.ir, sabaghnia@yahoo.com
}

Communicated by Isaak Rashal

\begin{abstract}
Landraces of spinach in Iran have not been sufficiently characterised for their morpho-agronomic traits. Such characterisation would be helpful in the development of new genetically improved cultivars. In this study 54 spinach accessions collected from the major spinach growing areas of Iran were evaluated to determine their phenotypic diversity profile of spinach genotypes on the basis of 10 quantitative and 9 qualitative morpho-agronomic traits. High coefficients of variation were recorded in some quantitative traits (dry yield and leaf area) and all of the qualitative traits. Using principal component analysis, the first four principal components with eigen-values more than 1 contributed $87 \%$ of the variability among accessions for quantitative traits, whereas the first four principal components with eigen-values more than 0.8 contributed $79 \%$ of the variability among accessions for qualitative traits. The most important relations observed on the first two principal components were a strong positive association between leaf width and petiole length; between leaf length and leaf numbers in flowering; and among fresh yield, dry yield and petiole diameter; a near zero correlation between days to flowering with leaf width and petiole length. Prickly seeds, high percentage of female plants, smooth leaf texture, high numbers of leaves at flowering, greygreen leaves, erect petiole attitude and long petiole length are important characters for spinach breeding programmes.
\end{abstract}

Key words: diversity, morpho-agronomic traits, principal component analysis, spinach (Spinacia oleracea L.).

Spinach (Spinacia oleracea L.) is an edible flowering plant from the Amaranthaceae family (Chenopodioideae subfamily), which is native to central and southwestern Asia and may survive over winter in temperate regions. Among leafy vegetables, spinach is characterised by having higher concentrations of nutrients calcium, magnesium, phosphorus, iron, and potassium as well as vitamins $\mathrm{A}, \mathrm{B}, \mathrm{E}$, and $\mathrm{K}$ (Kawashima and Soares, 2003). Also, it is known to contain high amounts of oxalic acid, which is formed as a secondary metabolite of vitamin C (Morelock and Correll, 2008). Spinach, as a dioecious species is an herbaceous leafy vegetable with alternate, simple, and ovate to triangular-based shaped leaves (Vural et al., 2000). Morphological traits, such as colour, leaf size, and smoothness of the leaves are important for industrial targets. China, the United States, Japan, Turkey, Indonesia, France and Iran are the seven largest commercial producers of spinach in the world (Anonymous, 2012). Iran produced about 105 thousand tons and the average yield was $2100 \mathrm{~kg} \cdot \mathrm{ha}^{-1}$. The global average yield of spinach is $2420 \mathrm{~kg} \cdot \mathrm{ha}^{-1}$ and the average yield of spinach in China is $2768 \mathrm{~kg} \cdot \mathrm{ha}^{-1}$ (Anonymous, 2012).

Iranian spinach producers typically use local spinach landraces, which have good adaptability to local conditions, but their performance is very low compared with the highest global yields. Therefore, it is essential to conduct spinach breeding programmes for increasing its yield potential. Utilisation of the genetic potential of crop germplasm requires detailed knowledge about its genetic variation (Morelock and Correll, 2008). Some investigations have been performed in the past on some Iranian spinach landraces collections, but most of them are limited due to use of only univariate statistical methods or collected samples from a limited geographical range (Benedictos, 1999; Asadi and Hasandokht, 2007; Eftekhari et al., 2010). This investigation was undertaken to assess the genetic variability in spinach landraces collected from diverse agro-climatic conditions of Iran using several quantitative and qualitative 
morphological traits and determine relationships between the traits.

Fifty-four spinach landraces collected from different geographical regions of Iran were evaluated in the field in a randomised complete block design (RCBD) with four replications, during the 2014-2015 growing season at Maragheh $\left(37^{\circ} 23^{\prime} \mathrm{N}\right.$ and $\left.46^{\circ} 14^{\prime} \mathrm{E}\right)$. The field soil had loamy structure with low organic matter. Fertilisation was carried out with $80 \mathrm{~kg} \cdot \mathrm{N} \mathrm{ha}{ }^{-1}$. Plot size was $4.5 \mathrm{~m}^{2}$ with six $3-\mathrm{m}$ long rows and $0.25-\mathrm{m}$ spaces. Sowing was done by hand. Weed control was conducted by hand twice, when the weed density was high. Required cultural practices recommended for spinach were followed throughout the crop season. The harvested plot size, which consisted of four 2.5 -m centre rows, was $2.5 \mathrm{~m}^{2}$. Data for the qualitative as well as quantitative traits of spinach were recorded. The following spinach traits were measured on 10 random plants: leaf length (LL), leaf width (LW), petiole length (PL), petiole diameter (PD), leaf area (LA), leaf number at flowering (LN), days to flowering (DF), percentage female plants (FP), fresh yield (FY), and dry yield (DY) as quantitative traits.

The recorded qualitative traits were leaf texture $(\mathrm{LT}, 1=$ smooth, 2 = slight crinkled, 3 = crinkled), seed type (ST, $1=$ smooth, 2 = prickly), stem anthocyanin ( $\mathrm{SA}, 1=$ very low, 3 = low, 5 = intermediate, $7=$ high, $9=$ very high), petiole attitude (PA, 1 = erect, $2=$ semi-spared, $3=$ spared), vegetative leaf shape $(\mathrm{VL}, 1=$ elliptic, 2 = broad elliptic, $3=$ circular, $4=$ ovate, $5=$ broad ovate, $6=$ triangular), reproductive leaf shape (RL, $1=$ smooth, 2 = pointy); leaf edge (LE, $1=$ smooth, $2=$ rippler); leaf colour $(\mathrm{LC}, 1=$ yellow-green, 2 = grey-green, 3 = blue-green); and seed colour (SC, 1 = yellow-green, 2 = grey-green, 3 = blue-green). Trait selection and measurement techniques were based on descriptors developed by Bioversity International (Anonymous, 2013) as well as the International Board for Plant Genetic Resources (Anonymous, 1991). All of the traits had normal distributions, and thus no transformation was applied for the traits. For further analysis, a correlation matrix was used, which standardised the data, eliminating effect of parameters with different scales. Descriptive statistics such as means and coefficient of variation (CV) were determined. Principal components analysis (PCA) was used (Everitt and Dunn, 2010) and plots of the first two principal components were made. Although multiple correspondence analysis could be used instead of PCA, in any case, PCA is a more routine statistical analysis used by many authors (Dehghani et al., 2008; Eftekhari et al., 2010; Sabaghnia et al., 2011). Also, due to simultaneously analysis of both quantitative and qualitative traits, using PCA is more practical (Manly, 2004). The variance explained by principal components, communality (variance explained by each parameter and correlation coefficients between parameters and components were determined (Spencer, 2013). The experimental data were statistically analysed using minitab version 16 (Anonymous, 2010) software.

The results of principal components analysis for quantitative traits are shown in Table 1. The first four principal
Table 1

PRINCIPAL COMPONENTS LOADINGS OF QUANTITATIVE TRAITS OBTAINED FROM 54 SPINACH LANDRACES

\begin{tabular}{lcccccc}
\hline Variable & PC1 & PC2 & PC3 & PC4 & $\begin{array}{c}\text { Commun- } \\
\text { ality }\end{array}$ \\
\hline LL & 0.341 & 0.146 & -0.203 & -0.479 & -0.195 \\
LW & 0.333 & 0.431 & 0.072 & 0.247 & 1.083 \\
PL & 0.317 & 0.378 & 0.182 & 0.133 & 1.010 \\
PD & 0.308 & -0.339 & -0.117 & -0.463 & -0.611 \\
LA & 0.383 & 0.316 & -0.025 & -0.068 & 0.606 \\
LN & 0.325 & 0.084 & 0.162 & 0.099 & 0.670 \\
DF & 0.226 & -0.338 & -0.144 & 0.668 & 0.412 \\
FP & 0.045 & 0.115 & -0.921 & 0.128 & -0.633 \\
FY & 0.376 & -0.365 & 0.063 & 0.029 & 0.103 \\
DY & 0.362 & -0.410 & 0.085 & 0.021 & 0.058 \\
& & & & & \\
Eigenvalue & 5.06 & 1.54 & 1.09 & 1.01 & 8.70 \\
Proportion & 0.51 & 0.15 & 0.11 & 0.10 & 0.87
\end{tabular}

LL, leaf length $(\mathrm{cm}) ; \mathrm{LW}$, leaf width $(\mathrm{cm})$; PL, petiole length $(\mathrm{cm}) ; \mathrm{PD}$ petiole diameter $(\mathrm{mm})$; LA, leaf area $\left(\mathrm{cm}^{2}\right)$; LN, leaf numbers in flowering; DF, days to flowering; FP, female plants percent; FY, fresh yield $\left(\mathrm{kg} \cdot \mathrm{ha}^{-1}\right)$; DY, dry yield $\left(\mathrm{kg} \cdot \mathrm{ha}^{-1}\right)$.

components (eigenvalues $>1$ ) explained $87 \%$ of the variation for spinach landraces. The first principal component extracted can be regarded as yield performance vector ( $\mathrm{Ta}-$ ble 1). It had high loadings for fresh yield and dry yield traits, which were the related to yield characteristics. This principal component accounted for $51 \%$ of the total variation in quantitative traits of the spinach landrace data set. The second principal component was related to leaf properties and accounted for $15 \%$ of the total data variability. Among the spinach quantitative traits, this axis had high loadings for leaf width and leaf area traits. The third principal component was associated with petiole length and leaf numbers in the flowering vector (Table 1) and accounted for $11 \%$ of the total data variability. The fourth principal component had a high loading with days to flowering vector (Table 1) and accounted for $10 \%$ of the total data variability. Communality values for the measured quantitative traits of spinach are given in Table 1, which showed that leaf width, petiole length, leaf area and leaf numbers in flowering traits explained the highest amounts of variance.

Principal components analys is for qualitative traits showed that the first five principal components explained $79 \%$ of the variation for spinach landraces and these components had eigen values $>0.80$ (Table 2). The first principal component was associated with plant colour, as it had high loadings for leaf colour and seed colour and accounted for $30 \%$ of the total variation in qualitative traits of spinach landraces. The extracted second principal component was related to leaf texture and accounted for $17 \%$ of the total variability. The third principal component was explained by leaf edge vector and accounted for $13 \%$ of the total variability. The fourth principal component was related to vegetative leaf shape (Table 2), as this trait had high loadings on this 
Table 2

PRINCIPAL COMPONENTS LOADINGS OF QUALITATIVE TRAITS OBTAINED FROM 54 SPINACH LANDRACES

\begin{tabular}{lcccccccc}
\hline \multicolumn{1}{c|}{ Variable } & PC1 & PC2 & PC3 & PC4 & PC5 & $\begin{array}{c}\text { Commun- } \\
\text { ality }\end{array}$ \\
\hline LT & 0.004 & 0.600 & -0.079 & -0.324 & -0.278 & -0.077 \\
ST & -0.332 & 0.187 & 0.332 & -0.456 & 0.382 & 0.113 \\
SA & 0.278 & -0.145 & -0.391 & -0.651 & -0.056 & -0.965 \\
PA & 0.217 & -0.469 & -0.045 & -0.322 & 0.441 & -0.178 \\
VL & 0.413 & -0.156 & 0.398 & 0.199 & 0.173 & 1.027 \\
RL & 0.297 & -0.205 & 0.442 & -0.260 & -0.648 & -0.374 \\
LE & 0.271 & 0.385 & 0.504 & -0.112 & 0.277 & 1.325 \\
LC & 0.417 & 0.357 & -0.320 & 0.081 & 0.230 & 0.765 \\
SC & 0.509 & 0.146 & -0.137 & 0.182 & -0.004 & 0.696 \\
& & & & & & \\
Eigenvalue & 2.70 & 1.50 & 1.20 & 0.91 & 0.80 & 7.08 \\
Proportion & 0.30 & 0.17 & 0.13 & 0.10 & 0.09 & 0.79 \\
\hline
\end{tabular}

LT, leaf texture; ST, seed type; SA, stem anthocyanin; PA, petiole attitude; $\mathrm{VL}$, vegetative leaf shape; RL, reproductive leaf shape; LE, leaf edge; LC, leaf colour; SC, seed colour.

principal component and accounted for $10 \%$ of the total data variability. The fifth principal component was associated with petiole attitude and accounted for $9 \%$ of the total data variability (Table 2). Communality values of principal components analysis for the measured qualitative traits of spinach are given in Table 2. The results indicated that vegetative leaf shape, leaf edge, leaf colour and seed colour traits had the highest communality and consequently the high relative contribution in for qualitative traits of spinach.

Relations of quantitative traits of spinach with the first two principal components contributing about $66 \%$ of the variance are shown in Figure 1. The correlation coefficient between any two traits is approximated by the cosine of the angle between their vectors (Yan and Rajcan, 2002; Dehgahni et al., 2008). The correlation coefficients among the quantitative traits with relatively large loadings on PCA1 or PCA2 axis were high. The most prominent relations indicated by Figure 1 are: a strong positive association between leaf width and petiole length; between leaf length and leaf numbers in flowering; and among fresh yield, dry yield and petiole diameter traits, as indicated by the small obtuse angles between their vectors $(r=\cos 0=+1)$. There was a near zero correlation between days to flowering and leaf width and petiole length (Fig. 1) as indicated by the near perpendicular vectors $(r=\cos 90=0)$. Scattering of some variables was expected as the first two PCAs accounted for $\mathrm{d} \%$ of the total variation. Increased yield potential is an important goal for spinach breeders and progress in yield potential results from the progressive accumulation of genes conferring higher yield or elimination of the unfavourable genes through the breeding process. The present investigation showed that days to flowering and petiole diameter had strong relation with yield, suggesting the need to place more emphasis on these components for increasing the yield in spinach. The principal components analysis seems impor-

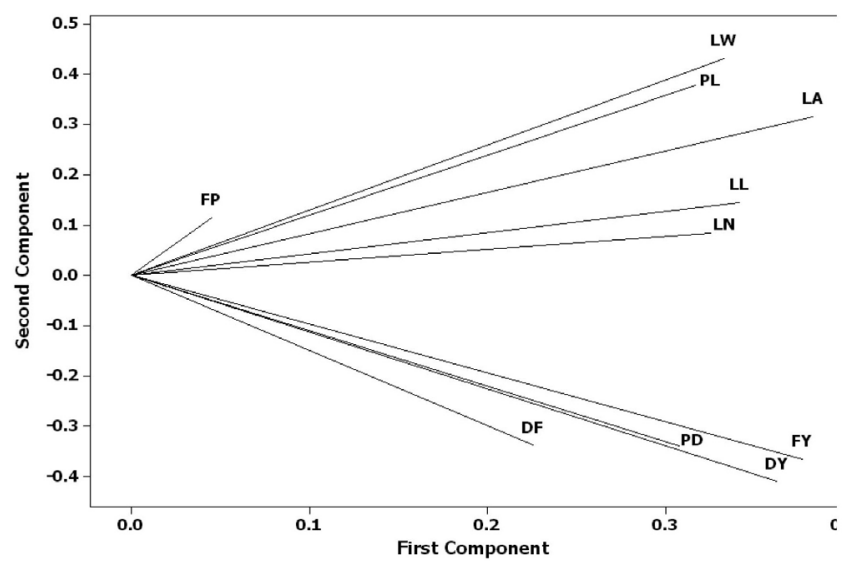

Fig. 1. Plot of first two principal components showing relation of various spinach quantitative traits.

tant, as the associated coefficients have relative magnitude consistent with breeding targets, and further work is required to compare multivariate methods with the aim of reaching actual gains.

The first two principal components of ordination of qualitative traits of spinach explained about half of the total variance (Fig. 2). The most prominent relations shown in Figure 2 were: a strong positive association among vegetative leaf shape, stem anthocyanin, and reproductive leaf shape traits, as indicated by the small obtuse angles between their vectors $(r=\cos 0=+1)$. There was a near zero correlation between leaf texture with seed colour; between leaf texture with seed type; between leaf edge with petiole attitude; between leaf texture with vegetative leaf shape, and stem anthocyanin and reproductive leaf shape traits as indicated by the near perpendicular vectors $(r=\cos 90=0)$. There was a negative correlation between seed type with vegetative leaf shape, stem anthocyanin, and reproductive leaf shape traits as indicated by the angle of approximately 180 degrees $(\mathrm{r}=$ $\cos 180=-1)$. Some discrepancies between the plot predictions and original data were expected because the first two PCAs accounted for $\mathrm{d} \%$ of the total variation. The statistical properties of PCA have been described in detail by some researchers (Dehghani et al., 2008; Sabaghnia et al., 2011).

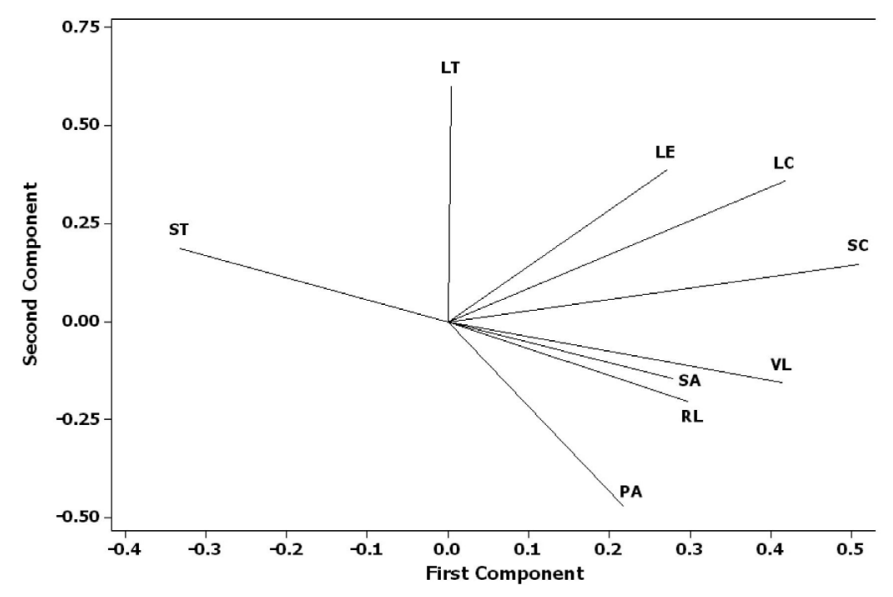

Fig. 2. Plot of first two principal components showing relation of various spinach qualitative traits. 
The principal components analysis may allow the plant breeders more flexibility in finding the number of plants to be evaluated. The plant breeder can use multivariate methods by first determining the combination of traits that constitute an ideal plant. By plotting the principal components in a single plot that are considered to be important, plants close to the ideal plant can be selected (Yan and Rajcan, 2002). This research was performed only for one growing season, and thus genotype-environment (GE) interactions maybe result in some discrepancies, but the results indicated that multidimensional methods can be sufficiently informative in choosing breeding directions.

In conclusion, investigated local spinach landraces collected from different geographical locations of Iran showed great variation with respect to yield potential and yield components. According to our results, petiole diameter and days to flowering maybe provide promising results for achieving high yielding cultivars. Hence these two traits should be used in breeding programmes to develop new spinach cultivars.

\section{REFERENCES}

Anonymous (1991). Descriptors for Beta. International Board for Plant Genetic Resources, Rome, Italy. 37 pp.

Anonymous (2010). MINITAB 16. MINITAB User's Guide. Minitab Inc, Harrisburg, Pennsylvania. USA. 374 pp.

Anonymous (2012). Food and Agriculture Organization of the United Nations. FAO STAT data. http://faostat.fao.org/ (accessed 17 July 2017).
Anonymous (2013). Bioversity International. The International Spinach Database. Centre for Genetic Resources. The Netherlands. Available at: http://documents.plant.wur.nl/cgn/pgr/spinach/ (accessed 30.01.2014).

Asadi, H. A., Hasandokht, M. R. (2007). An evaluation of genetic diversity of Iranian spinach landraces. Iranian J. Horticult. Sci., 38, 257-265.

Benedictos, P. (1999). Characterization and evaluation of spinach germplasm at the genebank. Publication no. 107.12.78335. Seed and Plant Improvement Institute (SPII). Karaj. Iran. 8 pp.

Dehghani, D., Omidi, H., Sabaghnia, N. (2008). Graphic analysis of trait relations of canola (Brassica napus L.) using biplot method. Agron. J., 100, 760-764.

Eftekhari, S. A. A., Hasandokht, M. R., Fatahi-Moghadam, M. R., Kashi, A. A. K. (2010). Genetic diversity of some Iranian Spinach (Spinacia oleracea L.) landraces using morphological traits. Iranian J. Horticult. Sci., 41, 83-93.

Everitt, B. S., Dunn, G. (2010). Applied Multivariate Data Analysis. Wiley. USA. 354 pp.

Kawashima, L. M., Soares, L. M. V. (2003). Mineral profile of raw and cooked leafy vegetables consumed in Southern Brazil. J. Food Compos. Anal., 16 (5), 605-611.

Manly, B. F. J. (2004). Multivariate Statistical Methods: A Primer. $3^{\text {rd }}$ edn. Chapman and Hall/CRC. 224 pp.

Morelock, T. E., Correll, J. C. (2008). Spinach. In: Handbook of Plant Breeding. Prohens, J., Nuez, F. (eds.). Springer, New York, pp. 189-218.

Sabaghnia, N. Dehghani, H., Alizadeh, B., Moghaddam, M. (2011). Yield analysis of rapeseed (Brassica napus L.) under water-stress conditions using GGE biplot methodology. J. Crop Improvement, 25, 26-45.

Spencer, N. H. (2013). Essentials of Multivariate Data Analysis. Chapman and Hall/CRC. 186 pp.

Vural, H., Esiyok, D., Duman, I. (2000). Vegetable Production. Aegean University Press, Bornova, Izmir, Turkey. 440 pp.

Yan, W., Rajcan, I. (2002). Biplot evaluation of test sites and trait relations of soybean in Ontario. Crop Sci., 42, 11-20.

Received 29 September 2014

Accepted in the final form 13 October 2016

\section{DAŽU KVANTITATĪVO UN KVALITATĪVO PAZĪMJU GALVENO KOMPONENŠU ANALĪZE IRĀNAS VIETĒJĀM ŠKIRNĒM}

Ar galveno komponenšu analīzi raksturotas vairākas kvantitatīvās un kvalitatīvās pazīmes 54 spinātu vietējām škirnēm, kuras ievāktas Irānas galvenajos spinātu audzēšanas reǵionos. Noteiktas pazīmes, kurām ir nozīmīga loma spinātu selekcijas procesā. 